[DOI: 10.24214/jecet.A.9.3.40115.]

Jaurnal of Environmental Science, Computer Science and Engineering \& Technology

An International Peer Review E-3 Journal of Sciences and Technology

Available online at www.jecet.org

Section A: Environmental Science

Research Article

\title{
Assessment of Ground, Raw, and Treated Surface Water Quality In and Around Al Bageer and Al Qoz Industrial Areas in Khartoum State-Sudan
}

\author{
Mahdi Haroun', Tisser Khalid², Abdelazim Mohd Altawil', Gammaa A. M. Osman³, \\ Eiman Elrashid Diab ${ }^{2}$
}

${ }^{1}$ Dept. of Environmental Health -College of Health Sciences-Jumeira University-Dubai- UAE

${ }^{2}$ Environment, Natural Resources, and Desertification Research Institute (ENDRI), National Center for Research, Khartoum, Sudan

${ }^{3}$ Sudan Academy of Sciences, Khartoum, Sudan

Received: 13 May 2020; Revised: 03 June 2020; Accepted: 07 June 2020

\begin{abstract}
Human activities had a vigorous part in the impact of water resources through discharge of industrials effluents, domestic discharge, and agricultural wastes. Water contaminated with toxic chemicals and pathogenic microorganism which can import many diseases for living things including human beings. Drinking water should be free from toxic chemicals, microorganism especially bacterial and safe for human consumption. This research work aim to investigate the fitness of water for drinking and food processing in and around $\mathrm{Al}$ Bageer and EL Qoz industrial areas in Khartoum State. Six sampling points (RSWN, RSBN, TSWN, TSBN, GWWN and GWBN) distributed throughout Al Bageer and EL Qoz were selected for investigation, 10 samples of each were prepared for laboratory analysis. All samples gave satisfactory results for the $\mathrm{pH}$, electrical conductivity (EC), total hardness, calcium, magnesium, sodium, total dissolved solids (TDS), total alkalinity, chlorides, fluoride, nitrates, sulphates, iron, and temperature. Turbidity was slightly high in raw surface water (35 NTU) than the ground water (34 NTU), according to Sudanese Standard Metrology Organization (SSMO) and World Health Organization (WHO).The surface water
\end{abstract}


samples shows sign of present of coliform total and fecal coliform hence they acceptable for drinking and food processing after decontamination, on other hand ground water samples of Al Bageer and El Qoz in Khartoum State (GWWN and GWBN) shows no sign of present for total coliform and E.coli, hence they considered satisfactory for the people and meet their requirements for potable water, because where comparable with the requirements of the Sudanese Standard Metrology Organization (SSMO) and World Health Organization (WHO).

Keywords: water quality, physical analysis, chemical analysis, microbiological analysis

\section{INTRODUCTION}

The significant of water is of no doubt, however, worldwide water supply is disapprovingly short especially to obtain safe water. The safe water is one of the most important assets. Contaminated water it is not only shocking the environment, but also the health of human beings, plants, and animals. Consequently, water should be observing, examining, assessing to keep continuous workable use ${ }^{[1]}$. Water is important to living organism. It is a medium for the majority of reactions (chemical, biological) and greatly critical for all livings events. World survey of studies tells that three quarter of earth surface is water. While it is astonishing, however despite such plenty of water, still a scarcity of potable water occur, since most of water is salty, which is inappropriate for utilization by human being ${ }^{[2]}$.

Sudan is considered biggest republic in zone of Africa and located generally in the dry district where water is a rare, it is wealthy in water resources ${ }^{[3]}$. Most of water in Sudan originates from resources of surface water, and groundwater is utilized in restricted zones. Nile River and its tributaries is considered the only sources for surface water. Khartoum State utilize supply of water delivered by stations from the Nile and several boreholes drilled at different parts of the city ${ }^{[4]}$.

Contamination of water is considered one of the difficult environmental keys in Sudan. This is principally logic for Khartoum capital compare to other states alongside the Nile, since Khartoum is the largest in Sudan with huge population. Aggregate per capita definitely increased the sewage difficulties ${ }^{[5]}$. Consequently, as no handling for discharge water is done might affect the quality of the river ${ }^{[6]}$.

Water contamination occur due to so many reasons, of which human activities is considered play the major part in river water contamination. Different kinds of industries were grown in the last decades in Sudan like (Leather, Sugars, petrochemicals, textile industries) and due to weak environmental regulation the discharge of these factories interfere with water in the river and causes contamination of the water of the Blue and White Nile.

This contamination change the physicochemical, and microbial conditions of the water like enlarged temperature and odor. Nevertheless, great content of certainly occurring elements e.g. $\mathrm{Ca}^{+2}, \mathrm{Na}^{+}, \mathrm{Fe}^{+2}$, and $\mathrm{Mn}^{+2}$, could have negative impacts on aquatic life. Photosynthesis is influenced by present and absent of molecular Oxygen. Additionally, turbidity might occur as a result of the anthropogenic activities that plug fish gills, ban light, disorders development of plant ${ }^{[7]}$. Furthermore, microbial species might yield waterborne infections ${ }^{[8]}$.

The whole industry in Sudan serve and follow stringent guidelines of the environmental council despite the condition of contamination is a way from satisfaction. Diverse law and regulation are subject to contamination capacity. The big industries have in situ handling services for dealing with their discharge. However small industrial establishment, could not have enough money to provide the 
necessary devices for handling their effluents. Accordingly, the contamination of water owing to contaminated materials has become threatening concern.

The current research work was carried out to investigate a number of physicochemical parameters and microbial analysis for drinking water quality of $\mathrm{Al}$ Bageer \& $\mathrm{Al} \mathrm{Qoz} \mathrm{Industrial} \mathrm{Areas} \mathrm{in} \mathrm{Khartoum}$ State-Sudan as well as the recognizing the micro flora of these sampling points.

Area of study: Khartoum, the national capital of Sudan, located in central Sudan at the junction of the Blue Nile and the White Nile Rivers. West of Nile River is the Omdurman town (Figure 1). Khartoum State occur between longitudes 31.5 to $34^{\circ} \mathrm{E}$ and latitudes 15 to $16^{\circ} \mathrm{N}$. This research work was done on Al Bageer \& Al Qoz Industrial Areas where located at both Blue Nile and White Nile River respectively; between the latitudes 140-24 ' N 280-33 ' E, and longitudes 150-00' N, 201- 33' E. The study area included Al Bageer area located around Blue Nile River and Al Qoz around White Nile River in Khartoum State (Fig 1).

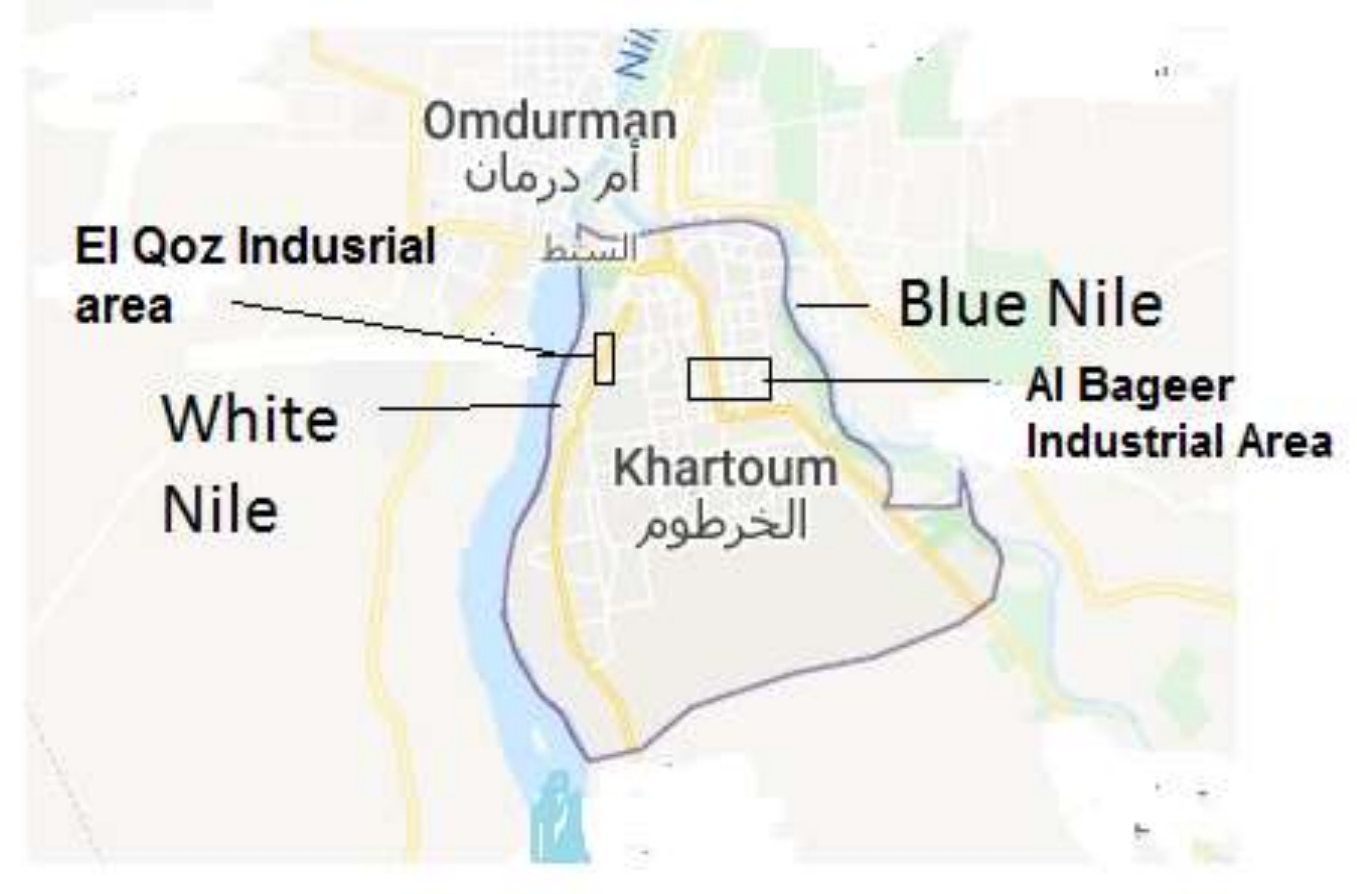

Figure 1: Map showing location of study area (Source- Khartoum - Wikipedia Google Maps)

\section{MATERIALS AND METHODS}

Sampling: Groundwater, treated water, \& untreated raw water (Surface) samples were obtained from Khartoum state alongside of Blue Nile River at Al Bageer industrial area and White Nile River at EL Qoz industrial area. Diverse sampling points is designated beneath in Table 1. The collected samples from Blue Nile and White Nile Rivers raw water (Surface) were diluted 1:5 with neutralized water before purification. Ground water \& treated water (Tape water) samples were diluted 1:2 before purification. Determination of a counts of faecal coliform were done per $100 \mathrm{ml}$ for each sample. Preservation of samples were done according to methods detailed by APHA ${ }^{[9]}$. All laboratory examination was done in the Laboratory in Ministry of environment and Soba Municipal station. 
Table 1: Sampling location

\begin{tabular}{|l|l|l|}
\hline Sample Number & \multicolumn{1}{|c|}{ Sources } & \multicolumn{1}{|c|}{ Description } \\
\hline RSBN & $\begin{array}{l}\text { Raw surface water in Blue } \\
\text { Nile River }\end{array}$ & $\begin{array}{l}\text { From Blue Nile surface water at Al Bageer } \\
\text { area }\end{array}$ \\
\hline RSWN & $\begin{array}{l}\text { Raw surface water in White } \\
\text { Nile River }\end{array}$ & $\begin{array}{l}\text { From While Nile surface water at El Qoz } \\
\text { area }\end{array}$ \\
\hline TSBN & $\begin{array}{l}\text { Treated Surface water in } \\
\text { Blue Nile River }\end{array}$ & from tape water at Al Bageer area \\
\hline TSWN & $\begin{array}{l}\text { Treated Surface water in } \\
\text { White Nile River }\end{array}$ & From tape water at El Qoz area \\
\hline GWBN & $\begin{array}{l}\text { Ground water in Blue Nile } \\
\text { River }\end{array}$ & From well at Al Bageer area \\
\hline GWWN & $\begin{array}{l}\text { Ground water in White Nile } \\
\text { River }\end{array}$ & From well at El Qoz area \\
\hline
\end{tabular}

Table 2: Parameters of Drinking Water Quality in Khartoum states with National and WHO Guidelines

\begin{tabular}{|c|c|c|c|}
\hline Parameters & Unit & $(\text { SSMO })^{[10]}$ & WHO $^{[11]}$ \\
\hline $\mathrm{pH}$ & units & $6.5-8.5$ & $6.5-8.5$ \\
\hline Electrical conductivity (EC) & $\mu \mathrm{mho} / \mathrm{cm}$ & 1000 & 1000 \\
\hline Temperature & ${ }^{\circ} \mathrm{C}$ & - & - \\
\hline Total Alkalinity & $\mathrm{mg} / \mathrm{l}$ & 200 & $500-1000$ \\
\hline Total dissolved solid (TDS) & $\mathrm{mg} / \mathrm{l}$ & 1000 & 1000 \\
\hline Hardness & $\mathrm{mg} / \mathrm{l}$ & 500 & 500 \\
\hline Turbidity & NTU & 5 & 5 \\
\hline Chlorite $(\mathrm{Cl})$ & $\mathrm{mg} / \mathrm{l}$ & 250 & 250 \\
\hline Fluoride (F) & $\mathrm{mg} / \mathrm{l}$ & 1.3 & 1.5 \\
\hline Nitrate $\left(\mathrm{NO}_{3}\right)$ & $\mathrm{mg} / \mathrm{l}$ & 10 & 10 \\
\hline Sulphate $\left(\mathrm{SO}_{4}\right)$ & $\mathrm{mg} / \mathrm{l}$ & 500 & 400 \\
\hline Calcium $(\mathrm{Ca})$ & $\mathrm{mg} / \mathrm{l}$ & $100-300$ & \\
\hline Magnesium $(\mathrm{Mg})$ & $\mathrm{mg} / \mathrm{l}$ & 50 & 50 \\
\hline Sodium $(\mathrm{Na})$ & $\mathrm{mg} / \mathrm{l}$ & - & 200 \\
\hline Iron $(\mathrm{Fe})$ & $\mathrm{mg} / \mathrm{l}$ & 0.30 & 0.30 \\
\hline Total viable count & MPN/100ml & - & - \\
\hline Coliform count & MPN/100ml & $10 \mathrm{MPN} / 100 \mathrm{ml}$ & $0 \mathrm{MPN} / 100 \mathrm{ml}$ \\
\hline Faecal coliform count & MPN/100ml & $0 \mathrm{MPN} / 100 \mathrm{ml}$ & $0 \mathrm{MPN} / 100 \mathrm{ml}$ \\
\hline Faecal streptococci count & MPN/100ml & $0 \mathrm{MPN} / 100 \mathrm{ml}$ & $0 \mathrm{MPN} / 100 \mathrm{ml}$ \\
\hline
\end{tabular}

Sampling techniques: In this investigation, a total of six sampling points were located on the Blue Nile River and White Nile (Al Bageer Industrial Area and El Qoz Industrial Area) of which 2 points from ground water (well water), 2 points from raw surface water (untreated), and 2 points from treated surface water (Tape water) and 10 samples from each sampling points. The World Health Organization water sampling techniques was implemented ${ }^{[10,12]}$. 
Investigation of microorganisms in water samples: Techniques of pour plate was used for determination of total viable count (TVC) ${ }^{[13]}$. Total bacterial counts per $\mathrm{ml}$ of colony forming units (c.f.u. $/ \mathrm{ml}$ ) was determined by colony counter and hand-tally. Fecal streptococcus was accounted by method of azide dextrose broth. Faecal streptococci, faecal coliform, Total coliform were numerated by method of membrane filtration ${ }^{[14]}$. Salmonella spp was identified by method of selenite broth. ${ }^{[15]}$.

Analysis of physicochemical water samples: Investigation of water were done in the examination lab by method of APHA ${ }^{[16]}$. $\mathrm{pH} \&$ temperature were done in situ, and determined by $\mathrm{pH}$-meter (HACH 2000), a calibrated EC meter (Jenway, 4310) was used for determination of electrical conductivity (EC). Spectrophotometer (HACH DR2800) was used for determine the hardness of $\mathrm{Ca}^{+2}$ and $\mathrm{Mg}^{+2}$. The metallic oxides exist in the ash, were transformed by dilute Hydrochloric acid into ions of calcium, magnesium, and sodium, elements were detecting by Atomic Absorption Spectrophotometer (AAS) according to APHA ${ }^{[17]}$. Determination of total dissolved solids (TDS) done in purification device by Rhoades methods $(1982)^{[18]}$. Alkalinity (TA) was determined by Jenkins et.al assay ${ }^{[19]} .\left(\mathrm{Cl}^{-1}\right),\left(\mathrm{F}^{-1}\right)$, $\left(\mathrm{NO}_{3}{ }^{-1}\right),\left(\mathrm{SO}_{4}{ }^{-2}\right), \&\left(\mathrm{Fe}^{+2}\right)$ were determined by using standard methods of analysis prescribed by APHA

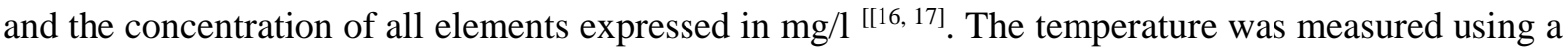
portable thermometer. Determination of turbidity was carried out by using EPA method and measured in nephelometric turbidity units (NTU) ${ }^{[7]}$.

\section{RESULTS AND DISCUSSION}

Examination of microorganism in samples of water: In the present investigation as it is shown in Table 3, both Al Bageer \& Al Qoz surface water samples in Khartoum state displayed total viable account in term of the coliform total and fecal coliform according to the both national and world health organization standards, consequently the samples of the Al Bageer \& Al Qoz surface water were polluted with detrimental microorganism that can be linked with health threats. The existence of those mentioned microorganism was the sign of contamination. Table 4 display the results of ground water samples of Al Bageer \& Al Qoz which show no sign for the present of microorganism, hence they considered satisfactory for the people and meet their requirements for potable water, because where comparable with the requirements of the national measures of drinking water in Sudan and world health organization (Table 2) ${ }^{[12]}$. The international organizations indicated that potable water proposed for drinking in any $100 \mathrm{ml}$ of colony forming unit, must be free from E.coli or total coliform bactria but in both sampling locations in Khartoum state surface water samples (treated and untreated) total coliform, fecal coliform and fecal Streptococci were detected, whereas wholly Al Bageer \& Al Qoz groundwater samples reflected the nonappearance of those microscopic sets. So the present of pollutants in treated and untreated water might be due to the inadequacy process of handling, corrosion of pipe-lines, and the contamination of water during distribution.

Table (3): Microbial load of Al Bageer \& Al Qoz Surface Water Samples (Treated \&Untreated) in Khartoum stats

\begin{tabular}{|l|c|l|c|l|c|c|}
\hline Sample & $\begin{array}{l}\text { Total viable count } \\
\text { (c.f.u./ml) }\end{array}$ & $\begin{array}{l}\text { total } \\
\text { coliform }\end{array}$ & F.Coli & $\begin{array}{l}\text { Yeasts and } \\
\text { Moulds }\end{array}$ & $\begin{array}{l}\text { Fecal } \\
\text { Streptococci }\end{array}$ & Salmonella \\
\hline RSBN & $4.5 \times 10^{4}$ & 54 & 25 & No Growth & - & - \\
\hline RSWN & $8.0 \times 10^{2}$ & 30 & 15 & No Growth & - & - \\
\hline TSBN & $3.6 \times 10^{4}$ & 10 & 55 & Few Fungi & 15 & - \\
\hline TSWN & $4.5 \times 10^{2}$ & 15 & 40 & Few fungi & 20 & + \\
\hline
\end{tabular}


Table (4): Microbial load of Al Bageer \& Al Qoz Ground Water Samples in Khartoum stats (CFU $/ \mathrm{ml})$

\begin{tabular}{|l|c|l|c|c|c|c|}
\hline Sample & $\begin{array}{l}\text { Total viable count } \\
\text { (c.f.u. } / \mathrm{ml} \text { ) }\end{array}$ & $\begin{array}{l}\text { total } \\
\text { coliform }\end{array}$ & F.Coli & $\begin{array}{l}\text { Yeasts and } \\
\text { Moulds }\end{array}$ & $\begin{array}{l}\text { Fecal } \\
\text { Streptococci }\end{array}$ & Salmonella \\
\hline GWBN & $4.5 \times 10^{4}$ & - & - & - & - & - \\
\hline GWWN & $8.0 \times 10^{2}$ & - & - & - & - & - \\
\hline
\end{tabular}

CFU $\equiv$ Colony Forming Unit

Physicochemical examination of water samples: In the current investigation to estimate the contamination condition, different samples were physicochemical investigated and the effects were matched with the regular level of Sudanese Standard Metrology Organization (SSMO) ${ }^{[10]}$ and World Health Organization (WHO) ${ }^{[11]} \cdot \mathrm{pH}$ is a techniques for determination of solution acidity or alkalinity. It oscillate between $0-14$, more than 7 is alkaline and less than 7 is acid. $\mathrm{pH}$ is play vital role in the chemical reactions in marine environment. Heavy metals toxicity is effective in specific $\mathrm{pH}$ value. Hence, $\mathrm{pH}$ having crucial significance in water quality determination. In the current study whole samples of water shows alkaline $\mathrm{pH}$ with the values oscillated among 7.3-8.0 which indicates that the $\mathrm{pH}$ value is in acceptable limits (Figure 2). And these values of $\mathrm{pH}$ reflect the hydrology of the area.

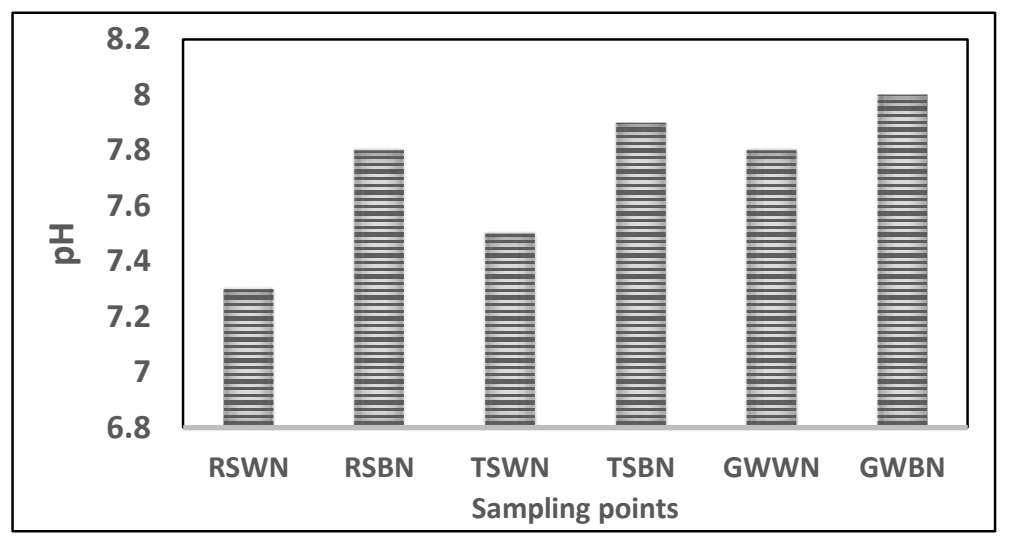

Figure 2: Trend of $\mathrm{pH}$ on different sampling points

Electrical conductivity (EC): is ability of water to transfer electrons. It shows the entire dissolved materials. Figure 3 depict EC values over the six sampling points which is ranged between 172 to 275 $\mu \mathrm{mho} / \mathrm{cm}$, which still within the acceptable limits of Sudanese Standard Metrology Organization $(\mathrm{SSMO})^{[10]}$ and World Health Organization (WHO) ${ }^{[11]}$ (Table 2). Generally the natural water exhibit conductivity among $150-400 \mu \mathrm{mho} / \mathrm{cm}^{[20]}$.

Water hardness: is owed to the presence of dissolved salts. It is occur as a result of natural buildup of salts from contact with soil and geological formations or it may enter from direct contamination by effluent of industries. Permanent hardness is caused due to dissolved calcium or magnesium sulphates which cannot be removed by boiling. Temporary hardness is caused due to dissolved magnesium or calcium hydrogen carbonates which can be removed by boiling. Figure 4 explain the total hardness concentration in $\mathrm{mg} / \mathrm{l}$ of water samples which fall among 70 to 110 , demonstrating that it within the acceptable level ${ }^{[21]}$. Hardness is essential water quality factor owing to existence of $\mathrm{HCO}_{3}, \mathrm{SO}_{4}, \mathrm{Cl}^{-1}$ and $\mathrm{NO}_{3}{ }^{-1}$ of $\mathrm{Ca}^{+2}$ and $\mathrm{Mg}^{+2}$. 


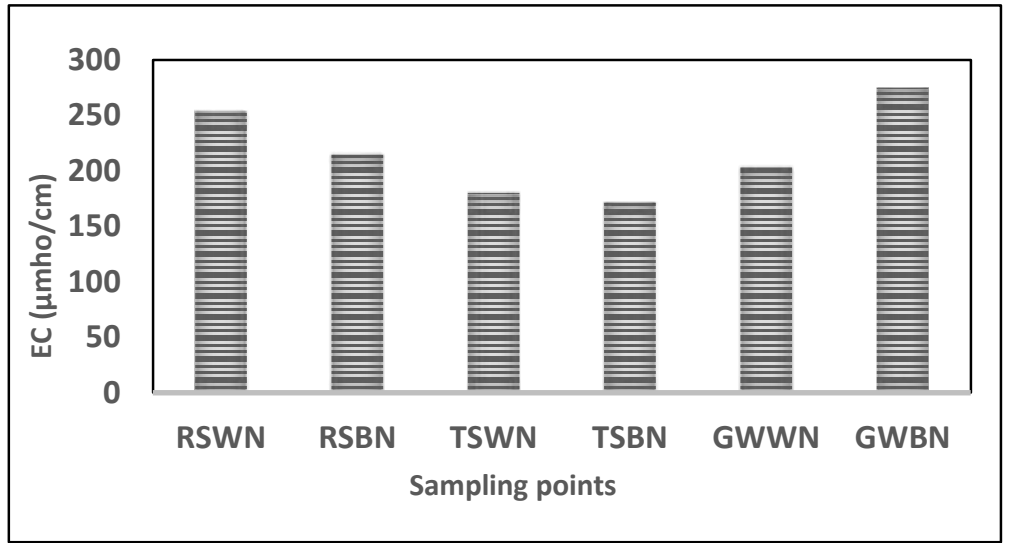

Figure 3: Trend of Electrical conductivity on different sampling points

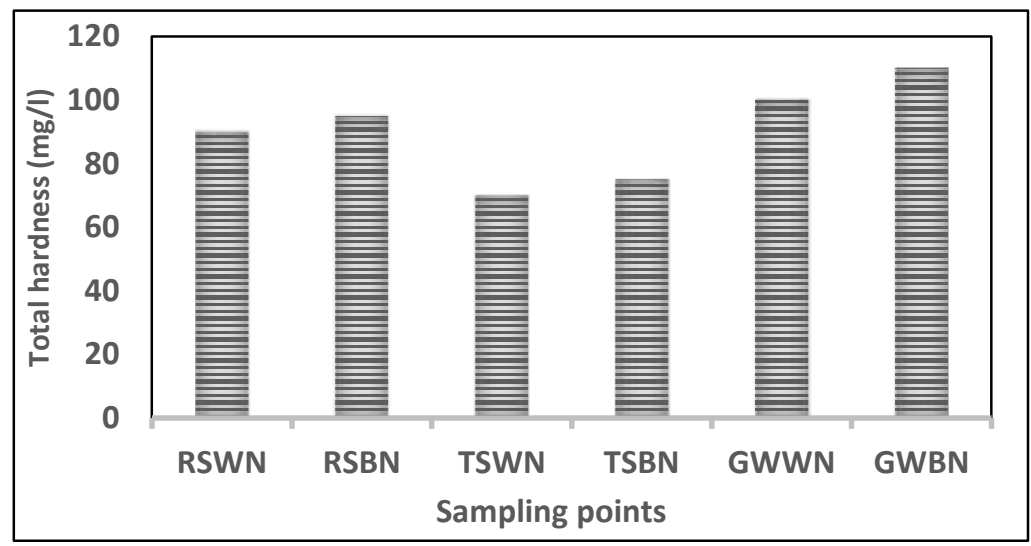

Figure 4: Total hardness on different sampling points

The existence of $\mathrm{Ca}^{+2}$ and $\mathrm{Mg}^{+2}$ in water result from breakdown of $\mathrm{Ca}^{+2}$ and $\mathrm{Mg}^{+2}$ alumino silicates at greater concentration, from disbanding of limestone, $\mathrm{Mg}^{+2}$ limestone, gypsum, and other minerals. The scope of calcium and magnesium in this study oscillating among 20.3 to 35.2 and 5.3 to $15.2 \mathrm{mg} / \mathrm{l}$ respectively (Figure 5), which both are below the range prescribed for the permissible level (Table 2). The decline in concentration of calcium and magnesium in water bodies might be owing to its absorption by living organisms ${ }^{[22]}$.

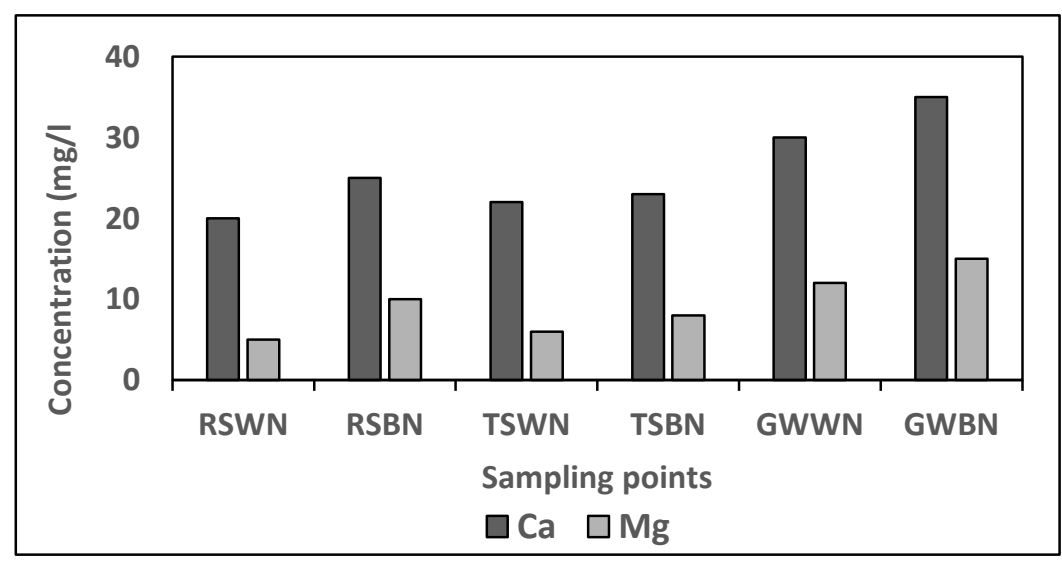

Figure 5: Distribution of Calcium and Magnesium on different sampling points 
The concentrations of sodium $\left(\mathrm{Na}^{+}\right)$exhibited greater concentrations. This is in same line with observations of Talling and Talling ${ }^{[23]}$. Figure 6 shows the sodium content throughout the sampling points which is ranged between 100 and $20 \mathrm{mg} / \mathrm{l}$ which is in the allowable level $(200 \mathrm{mg} / \mathrm{l})$ prescribed by the Standard Metrology Organization (SSMO) ${ }^{[10]} \&$ World Health Organization (WHO) ${ }^{[11]}$ (Table 2) (Figure 6), The element is unlikely to be a limiting nutrient for phytoplankton. Sodium concentration tended to be greater during the rainy period, in agreement with Ahmed et al., ${ }^{[24]}$ in the Nile within Egypt and Hall et al., ${ }^{[25]}$ in the Zambezi River who found greater levels of Na during the flooding.

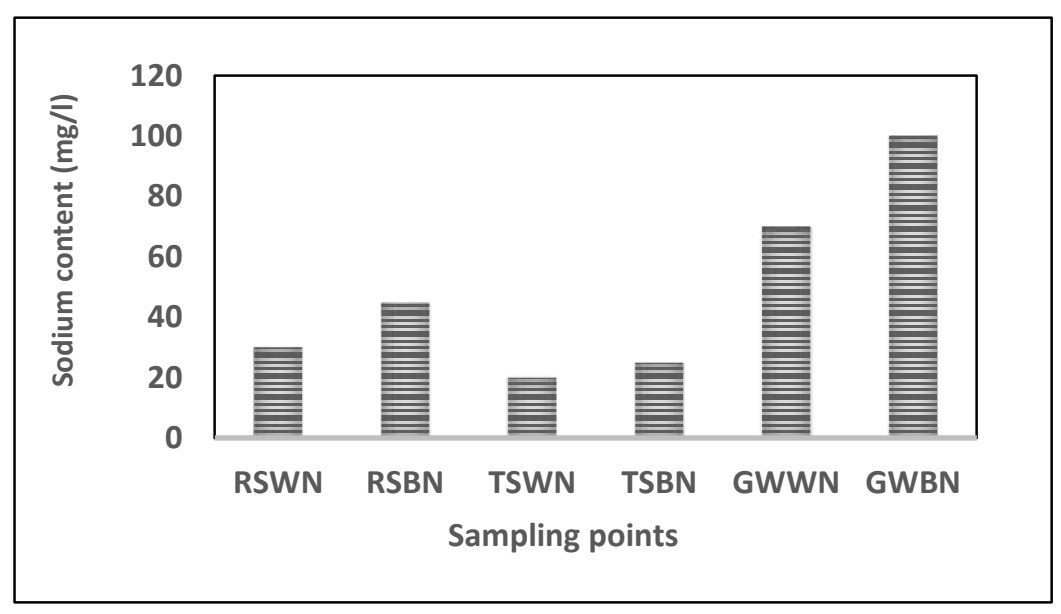

Figure 6: Sodium level $\left(\mathrm{Na}^{+}\right)$on different sampling points

Total dissolved solids (TDS): Greater content of this dissolved substances might cause opposing palate effects and gastrointestinal irritation ${ }^{[26]}$. Figure 7 show TDS values which varied from 170.5 to $140.13 \mathrm{mg} / \mathrm{L}$. All investigated samples points fall well within the permissible level, $500 \mathrm{mg} / \mathrm{l}$ (Table 2) designated by the Sudanese Standard Metrology Organization (SSMO) ${ }^{[10]}$ and World Health Organization $(\mathrm{WHO})^{[11]}$.

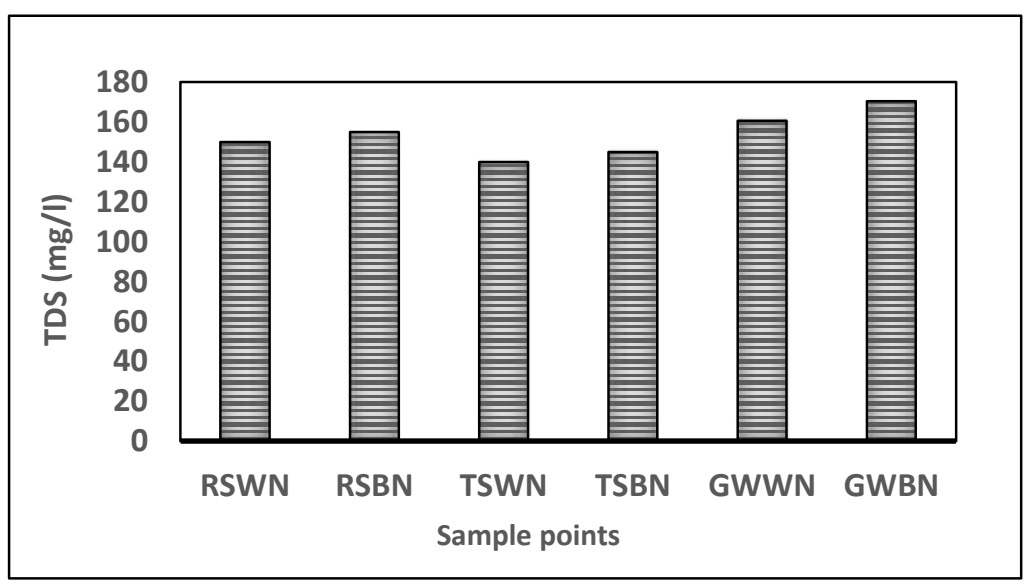

Figure 7: Total dissolved solids level (TDS) on different sampling points 
Total alkalinity in water samples was totally owed to the groups of $\mathrm{CO}_{3}^{-1}, \mathrm{HCO}_{3}^{-1}$, and $\mathrm{OH}^{-1}$. Hydroxide is unusual to normal water therefore no alkalinity of phenolphthalein noted for all investigated samples. The extreme and lowest levels of alkalinity noted through the current study were 100 and $70 \mathrm{mg} / \mathrm{l}$ as $\mathrm{CaCO}_{3}$ (Figure 8) which were below the acceptable level of alkalinity 500 $\mathrm{mg} / \mathrm{L}$ as $\mathrm{CaCO}_{3}$ as recommended by Sudanese Standard Metrology Organization (SSMO) ${ }^{[10]}$ and World Health Organization (WHO) ${ }^{[11]}$, (Table 2). These relatively high values of alkalinity indicate a sufficient reserve of total $\mathrm{CO}_{2}$ and sufficient source of inorganic carbon for the provision of algal photosynthesis ${ }^{[27]}$.

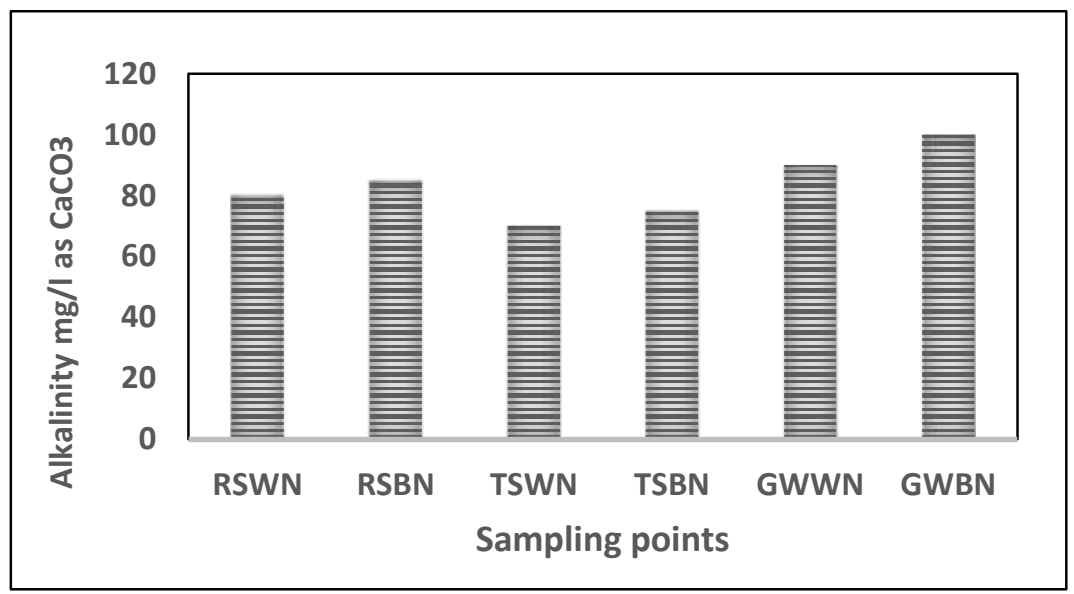

Figure 8: Total Alkalinity level on different sampling points

The content of chloride oscillate from 18.01 to $8.16 \mathrm{mg} / \mathrm{l}$ in all sampling points (Figure 9) which shows that the $\mathrm{Cl}^{-1}$ content is below the permissible level $(250 \mathrm{mg} / \mathrm{l})$ prescribed by Sudanese Standard Metrology Organization (SSMO) ${ }^{[10]}$ and World Health Organization (WHO) ${ }^{[11]}$ (Table 2). The ground water (well) had high chlorite content this could be produced by the close of the ground water (well) to the waste site. High chlorite content may cause corrosion ${ }^{[28]}$.

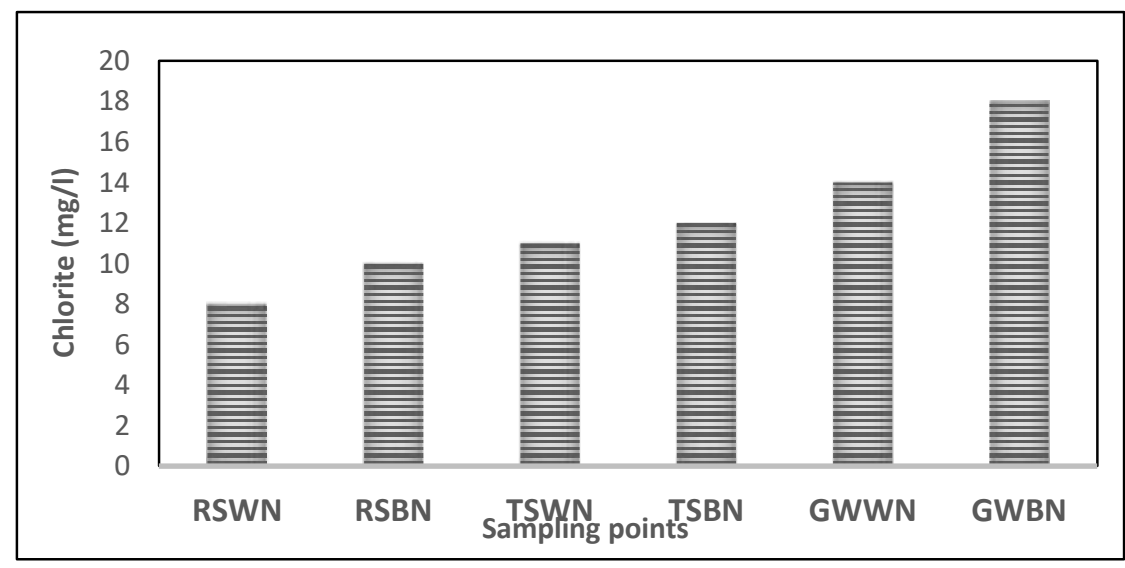

Figure 9: Chlorite level on different sampling points in Khartoum state

Figure 10 designates satisfactory levels for the fluoride in all sampling point of water which fluctuated from $(0.17-0.25 \mathrm{mg} / \mathrm{L})$, however, this fluctuation is well-thought-out adequate according to Sudanese Standard Metrology Organization (SSMO) ${ }^{[10]}$ and World Health Organization (WHO) ${ }^{[11]}$ (Table 2). It 
is recognized that the concentration of $(\mathrm{F})$ over $1.5 \mathrm{mg} / \mathrm{L}$ may produce difficulties like browning of teeth and spots of skin ${ }^{[10]}$.

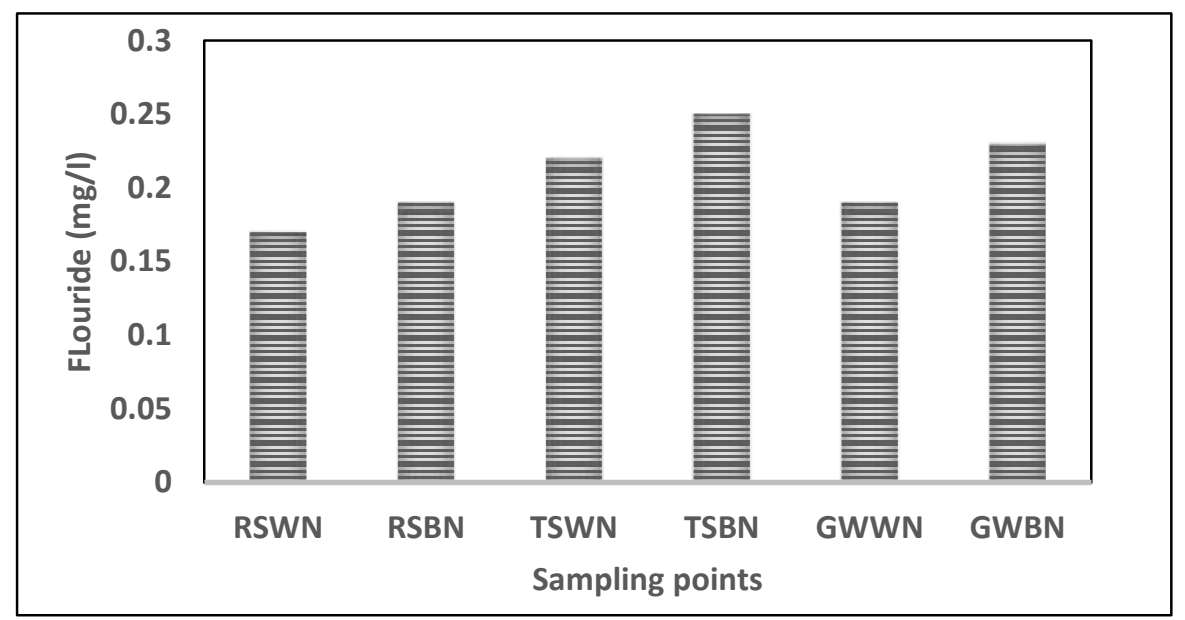

Figure 10: Fluoride level (F) on different sampling points

The present of nitrate $\left(\mathrm{NO}_{3}\right)$ in raw water is generated from chemical and fertilizer factories, animal's matters and vegetables, domestic and industrial discharge. Figure 11 showing nitrate concentration which was less than the permissible level $(10 \mathrm{mg} / \mathrm{l})$ prescribed by Sudanese Standard Metrology Organization (SSMO) ${ }^{[10]}$ and World Health Organization (WHO) ${ }^{[11]}$ (Table 2). Nitrates in raw water is a sign of the existence of oxidized organic matter. The study also indicates that the ground water have slightly high level of oxidized organic matter than the treated surface and untreated one, which looks in the form of soluble anions such as nitrates.

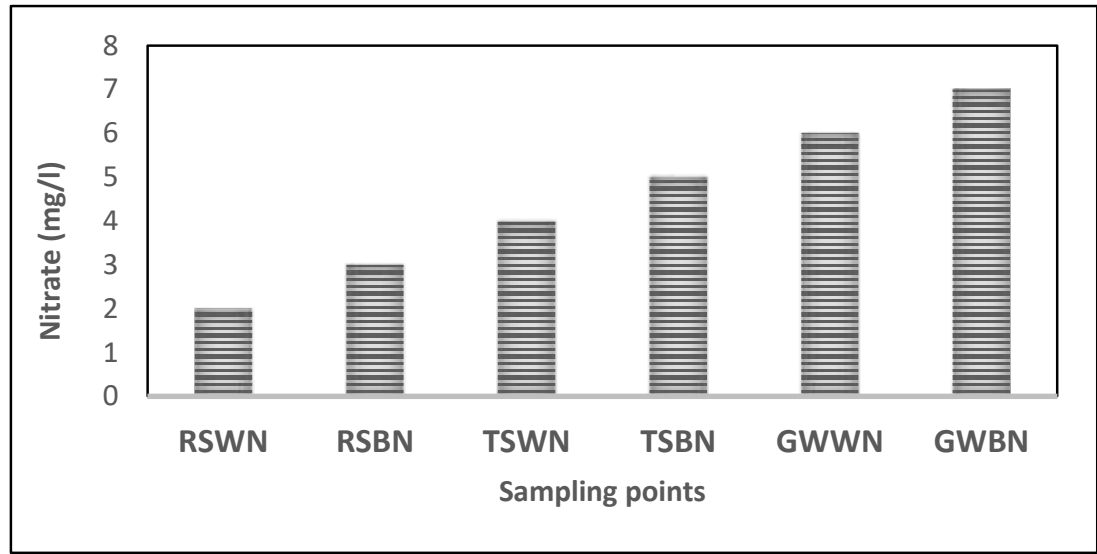

Figure 11: Nitrate $\left(\mathrm{NO}_{3}^{-1}\right.$ level on different sampling points

Sulphate is considered an important anion in potable water since it yields laxative influence on living things (human and animals) once it is exist beyond acceptable level. The $\mathrm{SO}_{4}{ }^{-2}$ content differ from 23.5 to $8.5 \mathrm{mg} / \mathrm{l}$ in all the sampling points (Figure 12). $\mathrm{SO}_{4}{ }^{-2}$ content in this work is under allowable boundary of 500/400 mg/l said through Sudanese Standard Metrology Organization (SSMO) ${ }^{[10]}$ and World Health Organization (WHO) ${ }^{[11]}$ (Table 2), whose values are well within the limit. $\mathrm{SO}_{4}{ }^{-2}$ are made 
owing to the breakdown of several sulphur materials exist in water bodies. $\mathrm{SO}_{4}{ }^{-2}$ arise obviously in all water bodies ${ }^{[29]}$. Great contents of $\mathrm{SO}_{4}{ }^{-2}$ can produce destruction to pipeline line, increase corrosion of steel, iron, and aluminum, yet, owed to the act of $\mathrm{SO}_{4}^{-2}$ it is worth stating in drinking water [29].

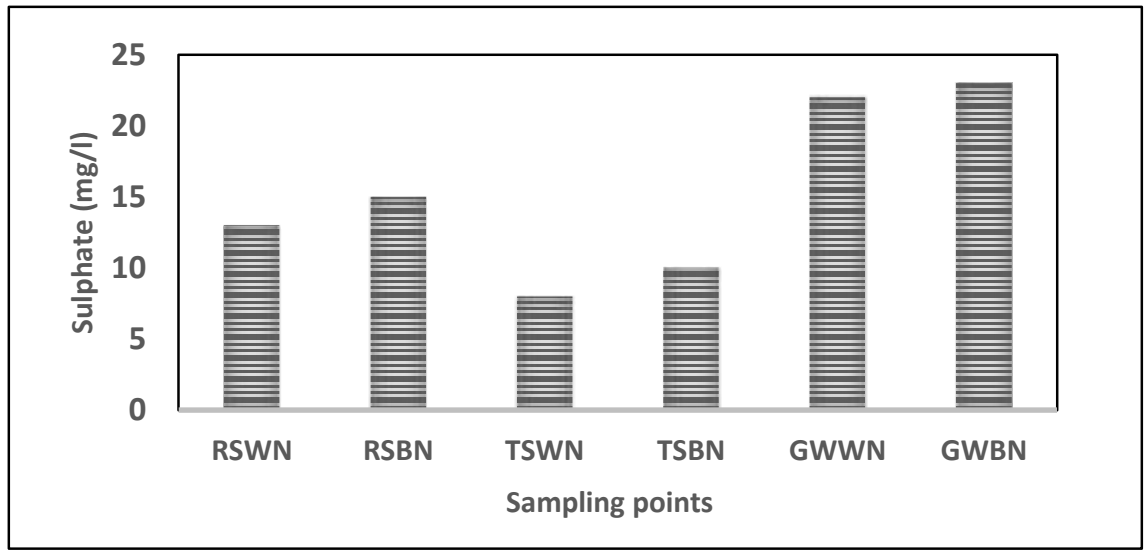

Figure 12: Sulphate $\left(\mathrm{SO}_{4}{ }^{-2}\right)$ level on different sampling points

Iron is considered carcinogen element. Figure 13, shows the iron content in all investigated sampling points which is fluctuated from 0.27 to $0.19 \mathrm{mg} / \mathrm{l}$ in the surface water (Raw) for Al Bageer and El Qoz industrial areas respectively. The treated water (tap water) in Al Bageer contained a higher level $(0.42$ $\mathrm{mg} / \mathrm{l}$ ), whereas that of El Qoz was $0.35 \mathrm{mg} / \mathrm{l}$. In case of ground water, Al Bageer samples exhibit 0.27 $\mathrm{mg} / \mathrm{l}$, and El Qoz $0.22 \mathrm{mg} / \mathrm{l}$ which are still below the permissible limits $(0.3 \mathrm{mg} / \mathrm{l})$ prescribed by Sudanese Standard Metrology Organization (SSMO) ${ }^{[10]}$ and World Health Organization (WHO) ${ }^{[11]}$ (Table 2). However, part of sampling points ensuring iron content little pit great compared to available measures for potable water. It ranges between 0.35 to $0.42 \mathrm{mg} / \mathrm{l}$. Generally any increase of iron above the normal level generate problem of staining or coloring of cloths and utensils. In addition to that is not appropriate for textile dying bleaching, food, beverages ${ }^{[29]}$.

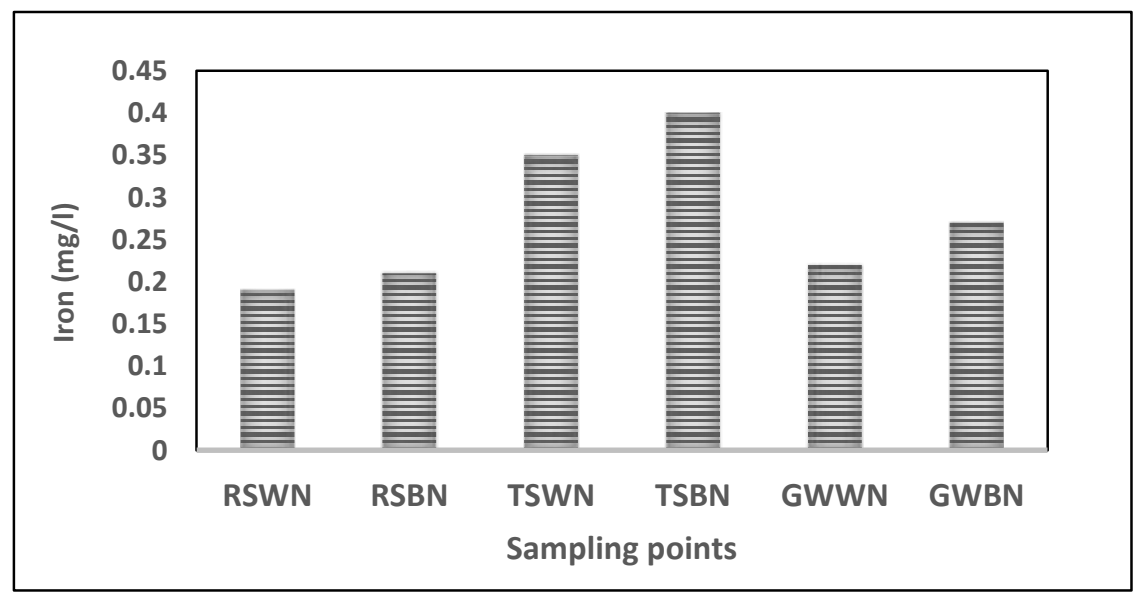

Figure 13: Iron level (Fe) on different sampling points 
Temperature is stated to effect the frequency of physical, biochemical processing and the life of aquatic animals and plants. Temperatures fluctuated from 25.3 to $28.8{ }^{\circ} \mathrm{C}$ for all sample points (Figure 14). Fewer dissolved gases and tastes detected in water having high temperature. Some researcher stated that spring water was slightly influenced by divergence of temperature ${ }^{[30]}$.

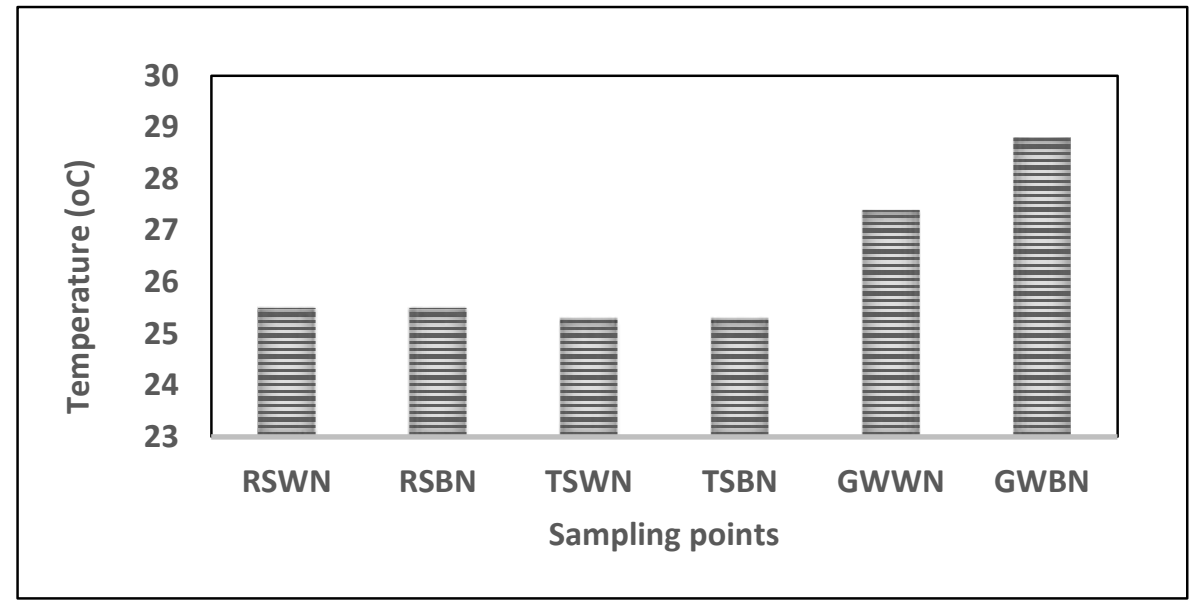

Figure 14: Temperature level $\left({ }^{\circ} \mathrm{C}\right)$ on different sampling points

Turbidity is a regular tool in testing in hydrology, where suspended residue is a major and beneficial part for assessing some microorganism like E. coli in water especially stagnant water (lake water) basins, and tanks. Dusty air play a vital role in initiating water turbidity in Sudan. Figure 15 display the trend of turbidity which was slightly high in raw surface water (35 NTU) than the ground water (34 NTU), and both are considered high in turbidity (turbidity <5 NTU) according to Sudanese Standard Metrology Organization (SSMO) ${ }^{[10]}$ and World Health Organization (WHO) ${ }^{[11]}$ (Table 2). Generally all natural waters bodies are turbid, and the surface water is more than the ground water. These turbid water may show the existence of threaten pathogen in these water sources. It is known that turbidity of value more than 5NTU upset form of water, and shelter microbial species from the effect of the sterilization and enhance the progress of microbial species, and offers increase to a substantial chlorine demand ${ }^{[31]}$.

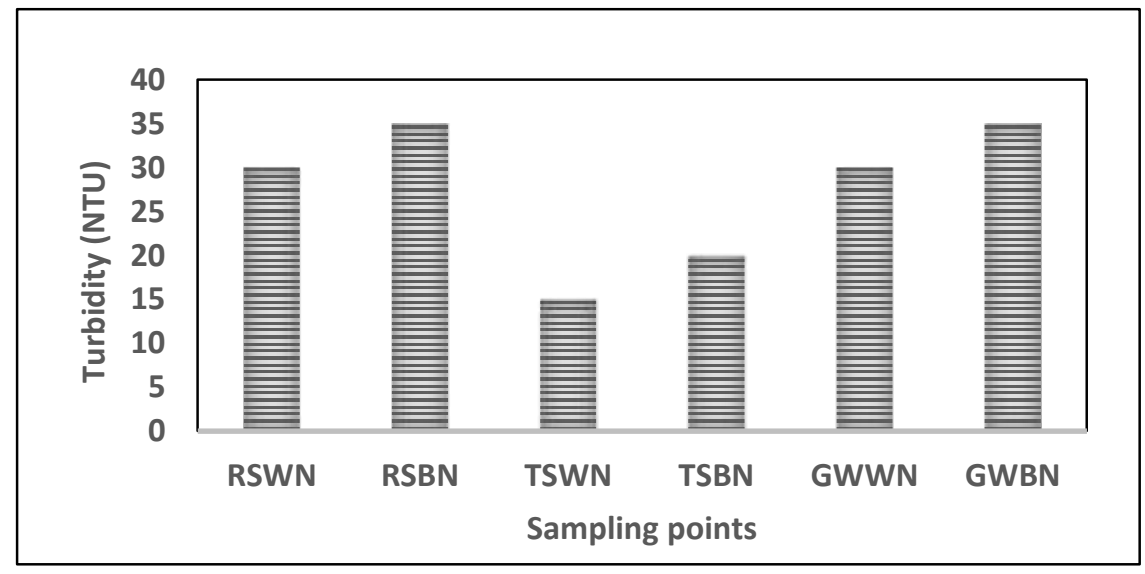

Figure 15: Turbidity level on different sampling points 


\section{CONCLUSION}

The main basis of water body's contamination is unwise release of raw municipal and sewage, discharge from industries without treatment into the water resources causing thoughtful contamination. From the current work, we can say that the Physico chemical factors of sampling points of ground water, treated, and untreated surface water in and around Al Bageer and El Qoz industrial area are in an acceptable levels prescribed by Sudanese Standard Metrology Organization (SSMO), however the toxicity of harmful chemical could interfere with the level of ground water if no safety methods were provided for operative handling of the discharged wastewater. According to outcomes of this study, the total dissolved solids of water samples taken from six sampling points (RSWN, RSBN, TSWN, TSBN, GWWN and GWBN) distributed throughout Al Bageer and EL Qoz in Khartoum state ranged between $140.13-170.5 \mathrm{mg} / \mathrm{L}$. This shows that there is no need for using additional filtration units to decrease the content of minerals salts in water. The combination of coagulation and flocculation techniques for handling of water is adequate for this task. Appropriate plan is recommended to reduce the microbial pollution and water handling charges.

\section{ACKNOWLEDGEMENT}

The authors wish to express their appreciation to National Centre for research and Soba treatment station for their kind cooperation in collecting the samples and support of analysis of this research.

\section{REFERENCES}

1. F.Zhou, G.H. Huang, H.C. Guo, W. Zhang and Z.J.Hao, Spatio-Temporal Patterns and Source Apportionment of Coastal Water Pollution in Eastern Hongkong. Water Research, 2007,41, 3429-3439.

2. S M Dhonde and G B Kulkarni, Hydro-Chemical Monitoring of drinking water in Kadi River at Nimgaon Choba project in Beed Dist.(M.S) INDIA, Bioscience Discovery,2012, 3(1):133.

3. Ibrahim, Microbiological Quality of water in some food factories storage cisterns in Khartoum north industrial area. Ph.D. thesis, Univ. of Khartoum, Sudan,2005, 54-60, 20-32.

4. M.Amira, Ell. Amin, E.S. Abdel Moneim, and A. El. Elamin, Quality Characteristics of Drinking Water in Khartoum State and Wad Medani District, Sudan. Fourteenth International Water Technology Conference, IWTC 14 2010, Cairo, Egypt, 2010.

5. A. Adukia, Sanitation and Education. Cambridge, MA: Harvard Graduate School of Education 2013.

6. M. Adamu, Z. A. Ahmad, J.M. Hafizan, R. Firuz, Surface water quality contamination source apportionment and physicochemical characterization at the upper section of the Jakara Basin, Nigeria. Arabian Journal of Geosciences, 2013, 6, 12, 4903.

7. EPA, "Protecting Water Quality from Agricultural Runoff." Fact Sheet No. EPA-841-F-05001,2005 .

8. C. M. Hoganl and A. Michael, Water pollution. Encyclopedia of Earth. Topic ed. Mark McGinley; ed. in chief C. Cleveland. National Council on Science and the Environment, Washington, DC. 2010. 
9. APHA, Standard methods for examination of waters and waste waters. 19th Ed., APHA, $A W W A$ and WPCF Inc. New York, 1995.

10. SSMO-044, Sudanese Standard and Metrology Organization, 2007.

11. WHO, Guidelines for drinking water quality, 2nd edition, Volume 3, Surveillance and control of community supplies, World Health Organization, Geneva.2008, 58-61.

12. WHO, Guidelines for drinking water quality, 2nd edition, Volume 3, Surveillance and control of community supplies, World Health Organization, Geneva, 1997, 58-61.

13. W.F. Harrigan, and M.E. McCance, Laboratory methods in Food and Dairy Microbiology, Academic Press, London, 1976.

14. Anon, The Microbiology of Water 1994. Part 1: Drinking Water. Report on Public Health and Medical Subjects, no. 71. London: HMSO, 1994.

15. APHA, Compendium of methods for the microbiological examinations of foods. 3rd Ed. (Vanderzant, C. and Splittosser, D. eds.), Washington, D.C., USA, 1992, 777-779.

16. APHA, Standard methods for examination of waters and waste waters. 19th Ed., APHA, $A W W A$ and WPCF Inc. New York, 1995.

17. A.P.H.A, American Public Health Association. Stan-dard Methods for the Examination of Water and Waste, 1980.

18. J.D. Rhoades, 'Soluble Salts): In A. L. Page, R. H. Miller and D. R. Keeney (eds), Methods of Soil Analysis, Part 2: Chemical and Microbiological Properties, 2nd ed., American Society of Agronomy, Inc, Madison, Wisconsin, 1982,U.S.A: 167-179.

19. S.R. Jenkins, J.M. Morgan, C.L Sawyer, Measuring anaerobic sludge digestion and growth by a simple alkalimetric titration. Journal of Water Pollution Control Federation, 1983, 55: 448453.

20. A.K. Adnan, S. Manoranjan, and R.B Panda,. Evaluation of Ground and Surface water Quality in and around Vedanta Aluminium Company at Jharsuguda, Odisha, India, International Journal of Current Engineering and Technology, 2013, 3(3):829-832.

21. D. P. Gupta, Sunita and J. P. Saharan, Physiochemical Analysis of Ground Water of Selected Area of Kaithal City (Haryana) India, Researcher,2009, 1 (2): 1-5.

22. O. J, Hemkes, A. Kemp, B. L. W. Van, Accumulation of heavy metals in the soil due to annual dressings of sewage sludge, New Zealand Journal of Agricultural Sciences, 1980, 28, 228-238.

23. J. F. Talling, and I. B. Talling, The chemical composition of the African Lakes waters. Int. Revue ges. Hydrobiol,1965, 50, 421-463.

24. M. A. Ahmed, A. A.Mohammed M.M. Heikal, A. A.Mohamed, and M. A. Zidan, Field and laboratory studies on the Nile phytoplankton in Eygpt. Some physical and chemical characteristics. Int.Revue ges. Hydrobiology, 1986, 71,127-138.

25. A., Hall, I. Valente, and B. R. Davies, The Zambezi River in Moçambique: The physicochemical status of the middle and lower Zambezi prior to the closure of the Cabora Bassa dam. Freshwat. Biol. 1977, 7, 187-206.

26. E.R.Plunkett,Handbook of Industrial toxicology,Chem. Publ.Coy.Ltd,Newyork,1976, pp;99101. 
27. F. Sinada and A. G. Abdel Karim, Physical and chemical characteristics of the Blue Nile and the White Nile at Khartoum, Hydrobiologia ,1984,110, 21-32.

28. K.A. Yusuf, Evaluation of ground water quality characteristics in Lagos-City. Journal of applied Sciences, 2007, 7(13):1780-1784.

29. P. K. Jena and M, Mohanty, Processing of liquid effluents of mineral processing industries, Intl Symposium Environ Manag Mining Metallurgical Industries, 11-14, Bhubaneshwar, 2005,pp 193-212.

30. K.O. Ipinmoroti, Water quality of shallow wells located close to dump sites in Akure, Nigeria, Pak.J.Sci.Ind.Res. 1993,36:137-141.

31. R. P. Mathur. Water and waste water testing, Nem Chand and Brothers, Publishers, Roorkee,1982, 1-54.

\section{Corresponding author: Mahdi Haroun,}

Dept. of Environmental Health -College of Health Sciences-Jumeira University-Dubai- UAE E mail: mahdikotsh@gmail.com

Date of publication online 08.06.2020 